\title{
SERVICE BLUEPRINT SEBAGAI SARANA PENUNJANG LOYALITAS CUSTOMER
}

\author{
Irawinne Rizky Wahyu Kusuma \\ Akademi Komunitas Manajemen Perhotelan Indonesia \\ winerichie88@gmail.com
}

\begin{abstract}
Abstrak
Penelitian ini bertujuan untuk mengetahui bagaimana sebuah pelayanan dapat dikatakan mampu memberikan kepuasan bagi pelanggan, hingga menciptakan loyalitas pelanggan. Hotel Crystal Kuta dengan konsep comfortable stay and ambience of Kuta, selain memberikan hasil pelayanan yang prima, juga memberikan kenyamanan, keamanan, dalam setiap pelayanannya serta keramahan dan privasi bagi pelanggannya. Service Blueprint diangkat sebagai salah satu patokan untuk memberikan guidance terhadap alur pelayanan. Kesan pertama terhadap sebuah jasa terjadi ketika service berlangsung harus lebih diperhatikan dikarenakan akan memunculkan perspektif pelanggan, seperti bagaimana pelanggan mendapatkan pelayanan, solusi yang tepat akan permasalahannya, kemudahan memperoleh fasilitas atau yang biasa dikenal dengan istilah moment of truth. Adanya Service Blueprint disini bertujuan untuk memahami praktek pelayanan dari sisi kacamata pelanggan, serta untuk memperkuat kontribusi dari masing-masing bagian dalam menjalankan perannya terhadap pelayanan. Penelitian ini adalah penelitian kualitatif dengan metode studi kasus dilakukan pada suatu kesatuan sistem yang berupa suatu kegiatan sekelompok individu yang ada pada keadaan atau kondisi pelayanan.
\end{abstract}

Kata Kunci: service blueprint, loyalitas customer

\section{PENDAHULUAN}

Pulau Bali terkenal dengan sebutan Pulau Dewata memiliki kesan tersendiri bagi para wisatawan mancanegara maupun domestik. Dikelilingi panorama alam yang memukau serta diiringi kentalnya budaya asli membuat Pulau Bali termasuk dalam salah satu daftar destinasi terbaik dari beberapa tujuan wisata popular lainnya diseluruh dunia. Situasi semacam ini dipergunakan oleh para penyedia layanan/ jasa sebagai peluang dalam membangun bisnisnya, baik disektor usaha perhotelan, spa, kuliner, pusat oleh-oleh dan sebagainya.
Philip Kotler (2007) mendefinisikan manajemen pemasaran sebagai seni dan ilmu memilih pasar sasaran dan meraih, mempertahankan, serta menumbuhkan pelanggan dengan menciptakan, menghantarkan dan mengkomunikasikan nilai pelanggan yang unggul. Dewasa ini, hospitality menjadi salah satu tolok ukur yang tidak bisa dilepaskan dari peran serta layanan. Sebagai titik awal dari membangun loyalitas customer, maka pelayanan harus tetap dijaga tanpa melupakan segi kualitas, begitu juga dengan bagaimana pemasarannya harus sudah dipikirkan.

Penyelenggara layanan/ jasa yang menerapkan Service Blueprint sebagai standar pelayanan merupakan bentuk dari 
aksi dan komunikasinya dalam menghadapi para pesaing. Service Blueprint menggambarkan sebuah alur secara matang yang digunakan sebagai pedoman layanan. Alur tersebut merupakan peran dari karyawan dan customer, dimana langkah - langkah aktivitas secara rinci dimunculkan untuk menciptakan keserasian dalam pelayanan serta dapat mengembangkan prosedur standar operasi pelayanan

Menurut F. Tjiptono (2000), kualitas pelayanan merupakan suatu pendekatan dalam menjalankan usaha yang mencoba untuk memaksimumkan daya saing organisasi melalui perbaikan terus menerus atas produk, tenaga kerja, proses dan lingkunganya. Kebanyakan perusahaan kurang memperhatikan kebutuhan pelanggan, serta kurang menggali potensi diri karyawan.

$$
\text { Service Blueprint awalnya }
$$

dipandang sebagai suatu program robot, yang mengharuskan karyawan mengikuti patron-patron tersebut secara continue. Namun sebenarnya Blueprint adalah rancangan yang digambarkan untuk memberikan arahan terhadap aktivitas pelayanan perusahaan yang dilakukan secara konsisten, jika service itu dilakukan dengan hati maka akan menjadi suatu hospitality yang mumpuni. Service Blueprint, secara tidak langsung mengikat suatu hubungan saling ketergantungan sebagai proyeksi yang luar biasa, dimana hospitality diharapkan dapat memberikan effect serta feed back yang luar biasa.

Dari latar belakang diatas maka dirumuskan masalah bahwa: (1) bagaimana service blueprint dapat menciptakan kepuasan bagi pelanggan?, (2) bagaimana kepuasan pelanggan bisa menciptakan loyalitas customer?

\section{MATERI DAN METODE}

Penelitian ini menggunakan penelitian kualitatif yang bersifat deskriptif dengan metode studi kasus dilakukan di Hotel Crystal Kuta pada suatu kesatuan sistem yang berupa suatu program kegiatan sekelompok individu yang ada pada kondisi pelayanan.

Pertama peneliti melakukan observasi kualitatif dimana peneliti terjun langsung dan berperan di lokasi penelitian. Dalam observasi atau pengamatan, peneliti juga melakukan pengamatan disetiap aktivitas- aktivitas yang terjadi di lokasi penelitian. Kedua peneliti melakukan wawancara kualitatif terhadap karyawan maupun customer, dan yang ketiga pengumpulan dokumendokumen kualitatif merupakan rekaman audio maupun visual.

Service Blueprint juga dikatakan sebagai titik tolak inovasi sebuah layanan. Pelayanan harus memiliki values: (1) Excellence, menghasilkan kinerja yang luar biasa, menunjukkan rasa empathi dan bekerja melebihi standar yang ditetapkan, (2) Dynamis, memiliki kemauan untuk bekerja lebih baik dan memiliki optimisme dalam menghadapi tantanga, (3) Partnership, membangun hubungan jangka panjang dan saling menguntungkan dengan pelanggan dan sesama karyawan, (4) Integrity, memelihara kejujuran dan bertanggung jawab penuh atas tindakan yang dilakukan, melakukan hal yang benar dengan kesadaran diri, (5) Social Concern, Bersikap peduli terhadap terciptanya lingkungan kerja yang aman.

Berbicara mengenai layanan/ jasa tidak terlepas dari model two way symmetrical Grunig dan Hunt (1984): Model komunikasi ini adalah model komunikasi dua arah. Tujuannya ialah keseimbangannya. Model ini tentang 
persuasi yang dapat memicu transaksi hingga popularitas dalam pemasaran. Dengan model ini tetap berusaha untuk memposisikan publik sebagai pihak yang harus berubah sesuai dengan keinginan organisasi dan bukan sebaliknya (Lattimore, 2010:64). Layanan/ jasa harus menyajikan sesuatu yang berbeda dan inovatif sehingga memiliki daya tarik tersendiri, namun tetap mengacu pada prinsip layanan 4P, yaitu product, price, place dan promotion.

Menurut Tjiptono (2008:219), pada hakikatnya promosi adalah suatu bentuk komunikasi pemasaran. Yang dimaksud dengan komunikasi pemasaran adalah aktivitas pemasaran yang berusaha menyebarkan informasi, mempengaruhi/ membujuk, dan/atau mengingatkan pasar sasaran atas perusahaan dan produknya agar bersedia menerima, membeli, dan loyal pada produk yang ditawarkan perusahaan yang bersangkutan.

Komponen yang harus ada dalam Service Blueprint adalah proses pelanggan, aktivitas front line, aktivitas backstage, serta dukungan sistem. Untuk memudahkan membayangkan bentuk Service Blueprint ini, saya ambil satu contoh tentang Blueprint layanan hotel yang dikemukakan oleh Zeithaml (2000).

Adapun komponen - komponen dalam service Blueprint yang mempengaruhi kepuasan pelanggan menurut Fitzsimmons (2011: 75), terdapat lima komponen pada Service Blueprint adalah sebagai berikut: (1) Physical Evidence, tekait hal-hal yang dapat dilihat oleh konsumen pada saat datang untuk mendapatkan pelayanan, seperti bentuk bangunan, halaman parkir, pintu masuk, dekorasi, pakaian karyawan, kursi dan meja, dan hal lainnya yang tampak. (2) Customer Action, berupa kegiatan yang dilakukan oleh konsumen untuk mendapatkan pelayanan. Berhubungan langsung dengan petugas front liner. (3) On Stage Contact Employee Action, kegiatan yang dilakukan oleh petugas front liner dalam melayani dan memenuhi kebutuhan atau keinginan konsumen. Pada bagian ini terjadi kontak antara konsumen dan karyawan yang sangat menentukan kepuasan pelanggan. (4) Back Stage Contact Employee Action, kegiatan yang dilakukan oleh petugas backstage, karyawan di back office yang mendukung pekerjaan karyawan front liner dalam pemenuhan kebutuhan konsumen. Pada bagian ini tidak ada kontak antara konsumen dan karyawan. (5) Support Processess, proses pendukung dalam usaha pemenuhan kebutuhan dan keinginan pelanggan.

\section{HASIL PEMBAHASAN}

Berikut hasil penelitian yang didapatkan oleh peneliti, langkah yang harus dilakukan dalam membuat sebuah Blueprint pelayanan harusnya mengacu kepada fasilitas pelayanan (service evidence) pada setiap langkah kegiatan konsumen.

Adapun komponen - komponen dalam service Blueprint yang berhasil diteliti dan membutuhkan perbaikan adalah pada komponen Physical Evidence yang masih belum terlihat seperti halaman parkir cukup luas namun masih perlu diperhatikan untuk: (1) memberikan petugas (security) selain berperan dalam menjaga keamanan, dapat ditambah dengan peran menyambut tamu ketika turun dari kendaraan seperti membukakan pintu mobil dan memberikan salam, (2) pada pintu masuk harus ada petugas (bell boy) yang membukakan pintu serta memberikan greetings dengan ciri khas perusahaan dan menanyakan keperluan customer kemudian mengarahkan kepada 
petugas selanjutnya. Sehingga memunculkan alur terhadap pelayanan. Selain itu customer juga akan merasa dirinya sangat dilayani dan diperhatikan. Jadi jika Service Blueprint benar-benar dijalankan, ini tidak hanya akan menjadi nilai lebih dari sebuah pelayanan namun dapat menmunculkan feed back yang luar biasa.

Dalam promosi juga sebaiknya ditekankan pada sisi (1) Personall kedekatan, (2) Prestige/ kebanggaan, (3) Proven/ pembuktian, (4) Pampering/ kenyamanan. Sehingga memberikan kemudahan bagi customer dan perusahaan menjalin relasi untuk memunculkan kepuasan pelanggan hingga loyalitas customer.

Selain daripada itu faktor lain yang mempengaruhi pelayanan adalah terkadang pelanggan enggan untuk menyampaikan komplain secara langsung, namun lebih memilih untuk menyampaikan komplain pada media tertentu. Disini dapat dilihat melalui web atau situs penjualan kamar seperti Traveloka, Rajakamar, Agoda yang memunculkan kolom komentar dibawahnya, Hotel Crytal Kuta mendapatkan beberapa komentar buruk mengenai pelayanannya. Ini yang seharusnya diminimalisir perusahaan, dikarenakan pelanggan tersebut tidak akan pernah kembali lagi, dan disisi lain kolom komentar akan dibaca ribuan orang yang ingin mencari referensi kamar, jika komentar lebih banyak buruk maka Hotel Crystal Kuta akan kehilangan pelanggannya dan kurang mampu bersaing dengan hotel - hotel bintang 2 lainnya.

\section{PENUTUP}

Menjadi suatu perusahaan besar harus memiliki visi dan misi yang kuat, serta mengetahui apa yang ingin dicapai. Selain itu terus mengevaluasi apa yang sudah dilakukan supaya dapat melakukan yang lebih baik dari yang sudah ada. Dapat disimpulkan pelayanan masih harus ditingkatkan lagi, jika dilihat dari pelayanan hospitality sudah cukup terarah dan sudah menciptakan kepuasan pelanggan. Namun disini penggunaan Service Blueprint masih sangat minim sehingga perlu digali kembali sehingga dapat memunculkan loyalitas customer.

Penulis berharap penelitian ini dapat memberikan sumbangan pemikiran kepada perusahaan jasa khususnya di bidang perhotelan. Serta dapat diaplikasikan untuk meningkatkan kualitas pelayanan hospitality sehingga siap bersaing dalam menyuguhkan aktifitas service yang inovatif, serta semakin memunculkan loyalitas pada seluruh pengguna jasa layanan.

\section{DAFTAR PUSTAKA}

Fitzsimmons, James $\mathrm{A}$ and Mona J. Fitzsimmons. 2011. Service Management: Operations, Strategy, Information Technology $7^{\text {th }}$ edition. New York: The McGraw-Hill International Edition.

Grunig, J. E. \& Hunt, T. (1984). Managing public relations. New York: Holt, Rinehart \& Winston.

Kotler, Philip. 2007. Manajemen Pemasaran, Jilid 2, Edisi 12. New Jersey: PT Indeks.

Lattimore, dkk. 2010. Public Relations: Profesi dan Praktik. Jakarta: Salemba Humanika.

Tjiptono, Fandy. 2000. Manajemen Jasa, Edisi Kedua. Yogyakarta: Andy Offset. 
Tjiptono, Fandy, 2008, Strategi Pemasaran, Edisi 3, Yogyakarta: Andy Offset.

Zethaml, Valerie A. (2000). Service Marketing: Integrating Customer Focus Across The Firm, Second Edition. New York: The McGrawHill International Editions. 